310

The Open Psychology Journal

RESEARCH ARTICLE

\title{
Structural Equation Model (SEM) of Matrilineal Parenting, Family and Community Environments on Adolescent Behavior in Padang City, Indonesia
}

\author{
Muhammad Natsir ${ }^{1}$, Ace Suryadi ${ }^{1}$, Mustofa Kamil ${ }^{1}$, Elih Sudiapermana ${ }^{1}$ and J. Julia ${ }^{2, *}$ \\ ${ }^{I}$ Department of Community Education, Universitas Pendidikan Indonesia, Bandung, Indonesia \\ ${ }^{2}$ Department of Elementary Teacher Education Program, Universitas Pendidikan Indonesia, Bandung, Indonesia
}

\begin{abstract}
:
Introduction:

This research aims to explain the effect of family and community environment on the causal relationship between matrilineal parenting and adolescent behavior.

Methods:

This research employs a survey with a cross-sectional design. The population was mothers with adolescent children living in Padang City, Indonesia. The survey was distributed using Google Form, and the data were analyzed using Partial Least Square-Structural Equation Modeling (PLS-SEM).

Results:

The analysis revealed five findings as follows: (1) family environment has a significant positive influence on adolescent behavior; (2) family environment has a positive influence on matrilineal parenting; (3) community environment does not have an influence on adolescent behavior; (4) community environment does not have an influence on matrilineal parenting; and (5) matrilineal parenting has a positive influence on adolescent behavior.

Conclusion:

Matrilineal parenting and the family environment greatly influence the behavior of adolescents. There are three matrilineal parenting components that provide guidance and direction to adolescents, namely mothers, fathers, and Mamak (uncle). When the matrilineal parenting style and family environment are good, adolescents have a strong personality that is not easily influenced by other factors.
\end{abstract}

Keywords: SEM-PLS, Adolescent behavior, Family environment, Community environment, Matrilineal parenting, Parenting.

\begin{tabular}{ll|l|r} 
Article History & Received: November 8, 2020 & Revised: March 31, 2021 & Accepted: April 20, 2021
\end{tabular}

\section{INTRODUCTION}

Adolescent age is often described as a period, which is full of spirit, involves the development of abilities and independence, but also is at risk of antisocial behavior and mental problems [1 - 3]. For example, adolescents are likely to get involved in various crimes of robbery, murder, and drug trafficking that affect their physical and psychological health in the future [4 - 6]. Thus, adolescents must have a strong personality that may not be disrupted by various negative factors [7]. The development of personality cannot be sepa

* Address correspondence to this author at Department of Elementary Teacher Education Program, Universitas Pendidikan Indonesia, Bandung, Indonesia; E-mail: juli@upi.edu -rated from a set of behavior owned by individuals. According to Kapetanovic and Skoog [8], behavior is defined as the potential and skills that individuals should inculcate to make their life good in a society or community. In other words, an individual can achieve a better life when they are capable of acquiring positive behavior that can also determine a strong personality. Individual behavior can be influenced by various factors. As is the case with adolescents, while the social environment such as school and peer groups greatly influence the behavior of adolescents [ 9 - 15], the interaction between family members can also be attributed to determine their personality development $[16,17]$. This indicates that parents have a significant role in strengthening the positive behavior of adolescents. 
Be Cheah [18] asserted that the mother's attention has a positive impact on the development of adolescents' strong personalities. Further, it is emphasized that adolescents with good behavior are pillars of future development. Being religious, honest, disciplined, independent, confident, creative, unyielding, polite, caring, cooperative, tolerant, and communicative are parts of good behavior. All of the behavior is manifested in suitable actions for themselves and others [19] consequently, it is very important to foster adolescents' behavior through parents' guidance and direction in the family $[20,21]$.

There are three factors that determine the behavior of adolescents, namely the environment in the family, parenting styles, and the community environment [8]. These factors contribute to the development of adolescents' personalities [9]. The community environment is proven to be beneficial for adolescents; for example, they can contribute to better school performance; be assiduous, confident, and optimistic; and reduce adolescent selfishness [22 - 24]. A good family environment will provide a sense of security and comfort for adolescents. In addition to attention from parents, family atmosphere, interaction with the family members and socioeconomic status, support the development of adolescents' behavior [25 - 29]. Therefore, parenting style determines adolescents' personalities. The parenting styles that have been implemented by parents, in general, are authoritarian, authoritative, and permissive parenting. The implementation of each style has a different impact on the behavior of adolescents [30 - 34].

One of the recent research on the behavior of adolescents was conducted by Cheah [18], in which, he examined the influence of parenting and social identity on the development of Muslim American adolescents' behavior. The research revealed that the mother's warmth moderates the relationship between religious socialization practices and the development of adolescents' positive behavior. Then, Lerner et al. [35] discussed the behavior that must be developed in adolescents, namely honest, humble, persevering, future-oriented, and goaloriented. Moreover, Yan-Li et al. [26] carried out the research whose findings revealed that there is a close relationship between the family environment, parental care, parental readiness, and adolescent behavior. In addition, Wagner [36] investigated the role of the strength of personality in peer relationships among early adolescents in Switzerland. The result showed that honesty, humorousness, kindness, and fairness are expected the most by teenagers from a friend. Furthermore, Sáenz et al. [37] revealed that the role of family members in providing support for children's education is vital.

Despite a plethora of research reports on the influence of parenting on adolescents' behavior, similar research on the context of matrilineal care has not been widely discussed. Based on the aforementioned gap, this article discusses the behavior of adolescents in matrilineal parenting, particularly the Minangkabau matrilineal system in Indonesia. The Minangkabau matrilineal system is one of the biggest societies in the world [38]. Matrilineal care is collective care different from conventional care in the nuclear family [39]. In the Minangkabau matrilineal system, caring is not only the responsibility of the parents but also the Mamak (uncle) [40, 41]. Mamak is the most important individual to look after his sister's children [42]. All the above-mentioned are involved collectively to form children's expected personality [43].

In light of the importance of matrilineal parenting for adolescent behavior, this recent research aims to determine the effect of matrilineal parenting on adolescents' personalities in the context of the Minangkabau matrilineal system [18, 44, 45]. Further, to address the aims, the researchers focused on the following research questions.

(1) How is the influence of the family environment on adolescent behavior?

(2) How is the influence of the family environment on matrilineal parenting?

(3) How is the influence of the community environment on adolescent behavior?

(4) How is the influence of the community environment on matrilineal parenting?

(5) How is the influence of matrilineal parenting on adolescent behavior?

\section{METHODS}

\subsection{Sample}

Utilizing a cross-sectional survey design [46], a total of 296 families were sampled using a multistage random sampling technique from a population of 11 districts in Padang City, West Sumatra, Indonesia. The age range of respondents was 15 years $-<64$ years. In terms of age, 4 respondents $(1.4 \%)$ were 20 years old, 24 respondents $(8.1 \%)$ were 21 - 40 years old, 264 respondents $(89.2 \%)$ were $41-60$ years old, and 4 respondents $(1.4 \%)$ were $<60$ years old. In terms of educational background, 24 respondents $(8.1 \%)$ were primary school graduates, 39 respondents $(13.2 \%)$ were junior high school graduates, 96 respondents $(32.4 \%)$ were senior high school graduates, $13(4.4 \%)$ had a diploma, 90 respondents (30.4\%) had a bachelor degree, $31(10.5 \%)$ had a master degree, and $3(1.0 \%)$ had a doctoral degree. Based on the occupations, 78 respondents $(26.4 \%)$ were civil servants, 157 respondents $(53.0 \%)$ were housewives, 21 respondents $(7.1 \%)$ were self-employed, 40 respondents $(13.5 \%)$ and 21 respondents $(7.1 \%)$ were private employees. The distribution of respondents based on the number of children is as folloes: 218 respondents $(74 \%)$ had $1-3$ children, 73 respondents $(25 \%)$ had 4-6 children, and 5 respondents (2\%) had 7-9 children. Lastly, in terms of Mamak, 240 respondents (81\%) had 1-3 Mamak, 52 respondents (18\%) had 4-6 Mamak, and 4 respondents (1\%) had 7-8 Mamak.

\subsection{Instrument}

This research employed a questionnaire comprising four variables: matrilineal care, adolescent behavior, family environment, and community environment. The questionnaire consisted of 147 items with a 5 point Likert scale design assessing the frequency of items, from 'always', 'often', 'sometimes', 'never', to 'never at all' (Table 1). 
Table 1. Variable and indicator.

\begin{tabular}{|c|c|c|}
\hline Variable & Indicator & $\begin{array}{c}\text { Questionnaire } \\
\text { Number }\end{array}$ \\
\hline \multirow{12}{*}{$\begin{array}{l}\text { Adolescent } \\
\text { Behavior }\end{array}$} & Religious & $1-6$ \\
\hline & Honest & $7-8$ \\
\hline & Discipline & $9-13$ \\
\hline & Independent & $14-17$ \\
\hline & Confidence & $18-22$ \\
\hline & Creative & $23-26$ \\
\hline & Never give up & $27-28$ \\
\hline & Respect and courtesy & $29-33$ \\
\hline & Care & $34-35$ \\
\hline & Cooperation & $36-37$ \\
\hline & Tolerance & $38-41$ \\
\hline & Communicative & $42-44$ \\
\hline \multirow[t]{3}{*}{$\begin{array}{l}\text { Matrilineal } \\
\text { Parenting }\end{array}$} & Authoritarian & $45-56$ \\
\hline & Authoritative & $57-74$ \\
\hline & Permissive & $75-92$ \\
\hline \multirow{4}{*}{$\begin{array}{c}\text { Family } \\
\text { Environments }\end{array}$} & Parents attention & $93-96$ \\
\hline & $\begin{array}{l}\text { Relationships between } \\
\text { family members }\end{array}$ & $97-108$ \\
\hline & Home atmosphere & $109-114$ \\
\hline & Socio-Economic Status & $115-118$ \\
\hline \multirow{4}{*}{$\begin{array}{c}\text { Community } \\
\text { Environments }\end{array}$} & Friends Associating & $119-127$ \\
\hline & Environmental lifestyle & $128-134$ \\
\hline & Activities in the community. & $135-142$ \\
\hline & Mass media & $143-147$ \\
\hline
\end{tabular}

\subsection{Procedure}

The questionnaire was distributed to participants using a Google Form. Before the questionnaire was distributed, it was tried out on mothers not included in the actual research sample and validated by three professors and a lecturer colleague who were experts in fields related to research variables. The Government of West Sumatra Province, Indonesia, had given official written approval to carry out this research. In addition, participants in this research had given their consent before filling out the questionnaire voluntarily. Withdrawal of participation from the research was also allowed at any time. The data collection was carried out for twenty days.

\subsection{Data Analysis}

This research used a theoretical model analysis with Partial Least Square-Structural Equation Modeling (PLS-SEM) and was assisted by SmartPLS 3.0 version 3.2.7 software [47]. PLS-SEM is a variant-based technique that has been widely used in the increasingly popular tourism, business, and technology research [48]. However, the technique is rarely used to explain the behavior of adolescents and parenting in families. Structural equation modeling based on Variance PLSSEM can be a suitable methodological alternative for testing covariance-based structural equation theory $[49,50]$.

This research refers to a general guideline for using PLSSEM with a two-step technique, namely evaluating the
Measurement Model (Outer Model) and designing the Structural Model (Inner Model). These two steps were conducted to analyze a theoretical research model [51, 52].

\section{RESULTS}

\subsection{Measurement Model (Outer Model)}

Evaluation of the feasibility of the measurement model and structural model has been carried out to ensure reliability and validity. Evaluation of the measurement (outer model) has been conducted to find out that each indicator in each variable has a good relationship with the other indicator. The outer model in Structural Equation Modeling-Partial Least Square (SEM-PLS) is evaluated through four stages, namely:

\subsubsection{Convergent Validity}

Convergent validity in SEM-PLS is also known as the loading factor. The level of convergent validity can be measured from the test results of loading factors. The indicator is valid if the value of loading factors is greater than 0.70 . The results of the output loading factors are presented in Table 2.

\section{Table 2. Loading factors.}

\begin{tabular}{|c|c|c|c|c|}
\hline & $\begin{array}{l}\text { Adolescent } \\
\text { Behavior }\end{array}$ & $\begin{array}{c}\text { Family } \\
\text { Environment }\end{array}$ & $\begin{array}{l}\text { Community } \\
\text { Environment }\end{array}$ & $\begin{array}{l}\text { Matrilineal } \\
\text { Parenting }\end{array}$ \\
\hline KR1 & 0.885 & & & \\
\hline KR10 & 0.854 & & & \\
\hline KR11 & 0.918 & & & \\
\hline KR12 & 0.916 & & & \\
\hline KR2 & 0.913 & & & \\
\hline KR3 & 0.831 & & & \\
\hline KR4 & 0.905 & & & \\
\hline KR5 & 0.914 & & & \\
\hline KR6 & 0.887 & & & \\
\hline KR7 & 0.940 & & & \\
\hline KR8 & 0.777 & & & \\
\hline KR9 & 0.935 & & & \\
\hline LK1 & & 0.896 & & \\
\hline LK2 & & 0.918 & & \\
\hline LK3 & & $0 ., 952$ & & \\
\hline LK4 & & 0.921 & & \\
\hline LM1 & & & 0.966 & \\
\hline LM2 & & & 0.902 & \\
\hline LM3 & & & 0.963 & \\
\hline LM4 & & & 0.938 & \\
\hline PPM1 & & & & 0.897 \\
\hline PPM2 & & & & 0.946 \\
\hline PPM3 & & & & 0.909 \\
\hline
\end{tabular}

Table 3 shows that the results of this research indicator have sufficient convergent validity because all indicators have a loading factor value greater than 0.7 , thus the indicators in this research were valid and this test was appropriate to be continued to the next stage. 
Table 3. Forner-larcker criterion, average variance extracted, cronbach's alpha and composite reliability values.

\begin{tabular}{|c|c|c|c|c|c|c|c|}
\hline & \multicolumn{9}{|c|}{ Forner-Larcker Criterion } & $\begin{array}{c}\text { Average } \\
\text { Variance } \\
\text { Extracted }\end{array}$ & $\begin{array}{c}\text { Cronbach's } \\
\text { Alpha }\end{array}$ & $\begin{array}{c}\text { Composite } \\
\text { Reliability }\end{array}$ \\
\hline & $\begin{array}{c}\text { Adolescent } \\
\text { Behavior }\end{array}$ & $\begin{array}{c}\text { Family } \\
\text { Environment }\end{array}$ & $\begin{array}{c}\text { Community } \\
\text { Environment }\end{array}$ & $\begin{array}{c}\text { Matrilineal } \\
\text { Parenting }\end{array}$ & & & \\
\hline Adolescent Behavior & 0.891 & & & & 0.793 & 0.976 & 0.979 \\
\hline Family Environment & -0.858 & 0.922 & & & 0.850 & 0.941 & 0.958 \\
\hline $\begin{array}{c}\text { Community } \\
\text { Environment }\end{array}$ & -0.906 & 0.777 & 0.943 & & 0.889 & 0.958 & 0.970 \\
\hline Matrilineal Parenting & 0.952 & -0.788 & -0.936 & 0.918 & 0.842 & 0.906 & 0.941 \\
\hline
\end{tabular}

\subsubsection{Discriminant Validity}

Based on the results of discriminant validity testing through the Fornell-Larcker criterion, the square root of AVE $(\sqrt{ })$ for each construct was greater than the correlation of each construct with other constructs, which was more than 0.70 . Thus, it can be concluded that the constructs or variables in this research had a good discriminant validity. The results of the Fornell-Larcker criterion test are presented in Table 3

\subsubsection{Average Variance Extracted (AVE)}

Average Variance Extracted (AVE) is conducted to determine the validity of each construct value. For constructs with good validity, the AVE value must be above 0.50 . Based on the results of the tests, all variables in this research had an AVE value of more than 0.50 . Therefore, all latent variables in this research were good at representing indicators. The results of the AVE test are presented in Table 3 .

\subsubsection{Composite Reliability and Cronbach Alpha}

The data processing using SmartPLS of each of the latent variables in this research showed that all variables had a Cronbach's alpha value and composite reliability of more than 0.70 . Therefore, all latent variables in this research were reliable and the model built had a very good level of reliability. The results of the value of composite reliability and Cronbach alpha are presented in Table Based on the results of the outer model by testing convergent validity, discriminant validity, average variance extracted (AVE), and composite reliability, it can be concluded that the outer model in this research had fulfilled the requirements specified in the stages of Structural Equation Modeling-Partial Least Square (SEM-PLS) research. Therefore, this research was appropriate to be continued to the next stage.

\subsection{Structural Model (Inner Model)}

Structural Model (inner model) is built in four stages, namely by looking at the results of the values of R-Square, Multicollinearity, F-Square (F2), Q-Square (Q2), and Goodness-of-Fit (GoF). The description of the test results of each test component is as follows:

\subsubsection{Results of R-Square}

$\mathrm{R}$-Square is used to determine how much the independent latent variable influences the dependent-latent variable in order to see the proportion of the dependent variable influenced by the independent variable. The $\mathrm{R} 2$ result of 0.67 indicates that the model is categorized as good, while the $\mathrm{R} 2$ result of 0.33 is categorized as moderate, and the R2 result of 0.19 is categorized as weak.

The results of SmartPLS 3.0 version 3.2.7 show that there were two values from the R-Square. The first R-Square obtained a value of 0.937 for the dependent variable of adolescent behavior with respect to the independent variables of matrilineal parenting, family environment, and community environment. The R-Square indicates that the independent variables of matrilineal parenting patterns, family environment, and community environment could explain the dependent variable of adolescent behavior by $93.7 \%$, while the remaining $6.3 \%$ was influenced or explained by other variables that had not been included in this research model. The R2 result of 0.937 indicates that the variables in this research model had a good relationship.

The second R-Square obtained a value of 0.885 for the dependent variable, matrilineal parenting, with respect to the independent variables of family environment and community environment. The R-Square indicates that the variables of family environment and community environment could explain the dependent variable of matrilineal parenting by $88.5 \%$, while the remaining $11.5 \%$ was influenced or explained by other variables that had not been included in this research model. The R2 result of 0.885 indicates that the variables in this research model had a good relationship.

\subsubsection{Results of Multicollinearity}

Multicollinearity is conducted to determine the correlation between constructs. Therefore, the relationship between one construct and another must be completely different. To find out whether multicollinearity existed between the constructs in SEM-PLS through SmartPLS 3.0 version 3.2.7, the results of the Variance Inflation Factor (VIF) value had been obtained. If the VIF value is $>5.0$, it can be considered that there is multicollinearity.

The results of the Variance Inflation Factor (VIF) test showed that the VIF value for each variable in the research was less than 5.0. Therefore, it has been concluded that the variables in this research were free from multicollinearity problems. In other words, the constructs built had different characteristics from other constructs so there was no need for construct changes. The results of the multicollinearity test are presented in Table 4. 
Table 4. Variance inflation factor.

\begin{tabular}{|c|c|c|}
\hline & $\begin{array}{c}\text { Adolescent } \\
\text { Behavior }\end{array}$ & $\begin{array}{c}\text { Matrilineal } \\
\text { Parenting }\end{array}$ \\
\hline Adolescent Behavior & & \\
\hline Family Environment & 2.728 & 2.527 \\
\hline Community Environment & 4.351 & 2.527 \\
\hline Matrilineal Parenting & 4.708 & \\
\hline
\end{tabular}

\subsubsection{Results of F-Square}

The results of the F-Square value test indicated that community environment variables had a weak influence on adolescent behavior because the result of the F-Square value test was 0.002 . The variable of family environment had a medium influence on matrilineal parenting due to the F-Square value of 0.079 . The variables of family environment and matrilineal parenting exhibited a strong influence because the F-Square values for each variable were 0.458 and 0.889 , respectively.

The variable of community environment had a strong influence on matrilineal parenting due to the F-Square value of 2.304. Therefore, the variables of matrilineal parenting and family environment for adolescent behavior and the variables of family environment and community environment for matrilineal parenting were suitable to be used in this research. Meanwhile, the predictive variable of the community environment for adolescent behavior was found to be less suitable to be used in this research.

\subsection{4.. Results of $Q-S q u a r e$}

The results of the Q-Square in this research indicated QSquare value to be 0.93 . Thus, the research model exhibited a good predictive value because the value was greater than zero, namely 0.93 . The result of the Q-Square test is as follows:

$$
\begin{aligned}
& \mathrm{Q} 2=1-\left(1-\mathrm{R} 1^{2}\right)\left(1-\mathrm{R} 2^{2}\right) \\
& =1-(1-0.937)(1-0.885) \\
& =0.93
\end{aligned}
$$

\subsubsection{Results of Goodness of Fit (GoF)}

Based on the data obtained from the previous SmartPLS output, the average AVE value was 0.843 , and the average value of R2 was 0.911. After obtaining the average AVE and R2 values, the next step was to calculate the Goodness of Fit value based on the formula below.

$$
\begin{aligned}
\text { GoF } & =\sqrt{A V E x R} \text { GoF }=\sqrt{A V E x R^{2}} \\
\text { GoF } & =\sqrt{0,844 \times 0,911} \\
& =0.876
\end{aligned}
$$

The GoF result was 0.876 , which was greater than 0.38 . Thus, it can be concluded that the model built had a good Goodness of Fit. After testing R-Square, Q-Square, and Goodness of Fit, the model formed has been considered as robust $[25,20]$. The outer model and inner model outputs of the SEM-PLS model that had passed the testing stages and found to be robust are as follows:

Fig. (1) shows that hypothesis testing can be done by determining the t-statistic value and the probability value. To test the hypothesis in this research, a significance level of 5\% was used so that the t-statistic value used was 1.96 . The criteria for accepting a hypothesis are based on t-statistics; if the tstatistic $>1.96$, then the hypothesis is accepted and vice versa. Furthermore, the criteria for rejecting or accepting the hypothesis are based on probability; if p-value $<0.05$, Ha is accepted.

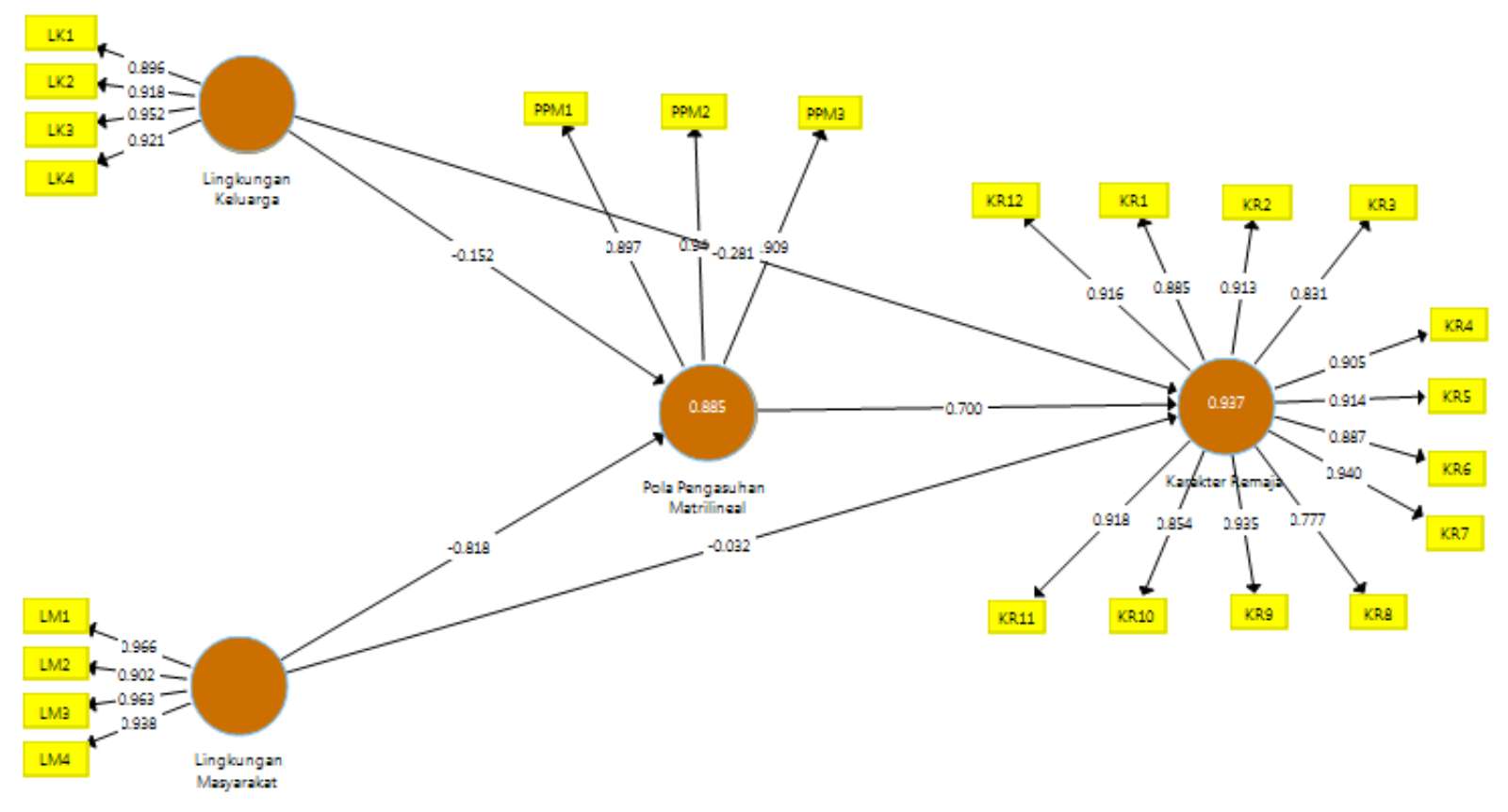

Fig. (1). PLS-SEM model output. 
Based on the bootstrapping test in the SmartPLS software shown in Fig. (1), the t-statistic value for the variables of family environment and matrilineal parenting with respect to adolescent behavior and the variables of family and community environment with respect to matrilineal parenting had shown a value above 1.96. Meanwhile, the variable of community environment for adolescent behavior had exhibited a t-statistic value below 1.96. Hypothesis testing in this research used a one-tailed test, which indicates whether it has a positive or negative effect. The acceptance or rejection of the hypothesis can be seen from the bootstrapping report in the Path Coefficient presented in Table $\mathbf{5}$.

Table 5. Path coefficient.

\begin{tabular}{|c|c|c|c|c|c|}
\hline & $\begin{array}{c}\text { Original } \\
\text { Sample } \\
\text { (O) }\end{array}$ & $\begin{array}{c}\text { Sample } \\
\text { Mean } \\
\text { (M) }\end{array}$ & $\begin{array}{c}\text { Standard } \\
\text { Deviation } \\
\text { (STDEV) }\end{array}$ & $\begin{array}{c}\text { T Statistics } \\
(\mid \mathbf{O} / \text { STDEV } \mid)\end{array}$ & $\begin{array}{c}\text { P } \\
\text { Values }\end{array}$ \\
\hline $\begin{array}{c}\text { Family } \\
\text { Environment } \\
->\text { Adolescent } \\
\text { Behavior }\end{array}$ & -0.281 & -0.285 & 0.029 & 9.581 & 0.000 \\
\hline $\begin{array}{c}\text { Family } \\
\text { Environment } \\
->\text { Matrilineal } \\
\text { Parenting }\end{array}$ & -0.152 & -0.154 & 0.026 & 5.842 & 0.000 \\
\hline $\begin{array}{c}\text { Community } \\
\text { Environment } \\
->\text { Adolescent } \\
\text { Behavior }\end{array}$ & -0.032 & -0.030 & 0.048 & 0.662 & 0.508 \\
\hline $\begin{array}{c}\text { Community } \\
\text { Environment } \\
->\text { Matrilineal } \\
\text { Parenting }\end{array}$ & -0.818 & -0.816 & 0.024 & 33.840 & 0.000 \\
\hline $\begin{array}{c}\text { Matrilineal } \\
\text { Parenting -> } \\
\text { Adolescent } \\
\text { Behavior }\end{array}$ & 0.700 & 0.700 & 0.054 & 12.858 & 0.000 \\
\hline
\end{tabular}

\section{DISCUSSION}

\subsection{The Influence of Family Environment on Adolescent Behavior}

The family environment is the first and major aspect that influences the behavior of adolescents. They spend more time in the family environment so family plays a significant role in developing their personality. The family greatly determines the good and bad behavior and the personality of adolescents [54]. Although, there are also other influential factors.

Based on the output path coefficients mentioned in Table 5 , the variable of family environment had been shown to have a positive and significant influence on adolescent behavior. This was evidenced by the t-statistic value of 9.581 , which was greater than 1.96, and the significance was recorded at alpha $5 \%$ (P-value $<0.05$ ). Thus, the hypothesis accepted H. In other words, the family environment had been found to exert a significant positive influence on adolescent behavior.

This result is in line with the findings in the research conducted by Krauss, Orth and Robins, which explains that various conditions in the family environment form the behavior of adolescents [52]. In addition, good communication and support provided by the family have a significantly positive influence on adolescent attitudes and behavior [55 - 57]. An unsupportive family environment for adolescents, such as a conflict between parents and violence in the family, initiates psychological disorders and affects the development of adolescent behavior $[29,58,59]$. Therefore, the family environment greatly determines the adolescent behavior.

\subsection{The Influence of Family Environment on Matrilineal Parenting}

The family environment also has an influence on parenting style in the family. The parenting style of families living in villages is different from those who live in cities [60, 61]. Likewise, the socioeconomic status of each family has an influence on parenting in the family [62 - 63].

Based on the output path coefficients listed in Table $\mathbf{5}$, the variable of family environment had been found to have a positive and significant influence on matrilineal parenting. This has been evidenced by the t-statistic value of 5.842 , which was greater than 1.96, and the significance was set at alpha 5\% (Pvalue $<0.05$ ). Thus, the hypothesis accepted $\mathrm{H}_{1}$.

This research reveals that a good family environment formulates the patterns of parenting in the family [64 - 65]. Interaction and cooperation in the family between parents and uncle (mamak) help to form better parenting. This provides many benefits for the family, but it is also very complex because both the parents and the uncle (mamak) must simultaneously carry out their roles as caregivers, and maintain relationships with each other [66 - 68].

\subsection{The Influence of Community Environment on Adolescent Behavior}

Community is one of the educational environments that strongly influence the personal development of adolescents. Besides the family, the community is the second natural environment known by adolescents. They need support from the surrounding environment in their development process [69, 70].

Based on several research findings, it is evident that the community environment influences the character of adolescents. Relationships with peers also influence the character of adolescents. However, some adolescent behaviors are not influenced by their peers $[71,72]$.

Based on the output path coefficients shown in Table $\mathbf{5}$, the variable of community environment had been found to exert a negative and insignificant influence on adolescent behavior. This is evidenced by the t-statistic value of 0.662 , which was less than 1.96, and the significance was set at alpha $5 \%$ (Pvalue $<0.05$ ). Thus, the hypothesis accepted $\mathrm{H}$.

The findings of this research reveal that the community environment does not have a significant influence on the behavior of adolescents, because the development of adolescents' personalities is mostly influenced by the family environment. Therefore, the community does not have a significant influence on adolescents' behavior.

\subsection{The Influence of Community Environment on Matrilineal Parenting}

Matrilineal parenting that involves parents and uncle (mamak) in the family is strongly influenced by geographical area, norms and culture of the local community, social partners, 
activities in the community, and the mass media [73 - 74]. Likewise, the lifestyle in the community also influences parenting [75].

Based on the output path coefficients shown in Table $\mathbf{5}$, the variable of community environment had been found to exert a positive and significant influence on matrilineal parenting. This has been evidenced by the t-statistic value of 33.840 , which was greater than 1.96 , and the significance was set at alpha $5 \%$ (P-value $<0.05$ ). Thus, the hypothesis accepted $\mathrm{H}_{1}$. In other words, the community environment had been found to have a positive influence on matrilineal parenting.

Parenting is related to the ability of a family or household and community to provide attention, time, and support to meet the physical, mental, and social needs of growing children. There are three parenting patterns, namely authoritarian, authoritative, and permissive parenting. Each of them affects the emotional, behavioral, and mental aspects of children [76].

\subsection{The Influence of Matrilineal Parenting on Adolescent Behavior}

The parenting styles received by children influence their behavior and personality [25]. Parents are the most basic role model in the family. If parents behave violently in the family, then children tend to imitate it. Likewise, if parents behave well in the family, the children also tend to behave well. Adolescents receive teachings and instructions given by parents [75]; therefore, the support of parents is favored by adolescents in their development. In matrilineal parenting, parenting is not only provided by parents but also involves mamak [51].

Based on the output path coefficients provided in Table $\mathbf{5}$, the variable of matrilineal parenting had been found to have a positive and significant influence on adolescent behavior. This has been evidenced by the t-statistic value of 12.858 , which was greater than 1.96 , and the significance was recorded at alpha 5\% (P-value $<0.05)$. Thus, the hypothesis accepted $\mathrm{H}_{1}$. In other words, matrilineal parenting had been shown to have a positive influence on adolescent behavior.

\section{CONCLUSION}

Based on the research findings, it can be concluded that (1) family environment has a positive and significant influence on adolescent behavior; (2) family environment has a positive and significant influence on matrilineal parenting (3) community environment does not have a positive influence on adolescent behavior; (4), community environment has a positive and significant influence on matrilineal parenting; and (5) matrilineal parenting has a positive and significant influence on adolescent behavior. Therefore, matrilineal parenting and family environment greatly determine the development of the adolescents' behavior. When parenting styles and family environments are good, the behavior of adolescents becomes stronger. Otherwise, when parenting styles and family environments are not good, the characters of adolescents become weaker. Thus, the cooperation of a mother, a father, and mamak in matrilineal parenting is very helpful to form strong adolescent characters.

\section{RECOMMENDATION}

The family (a mother, a father, and mamak) is expected to apply matrilineal parenting by collaborating in providing guidance to adolescents and creating a good family environment, thereby strengthening the behavior of adolescents in facing the wider community environment. Since this research involved a subject limited to mothers, the researchers provide recommendations for further research on the behavior of adolescents with broader research subjects.

\section{ETHICS APPROVAL AND CONSENT TO PARTI- CIPATE}

The West Sumatera provincial government approved this research with recommendation number 8.070 I 1179PERIZDPM\&PTSP/XIII2019.

\section{HUMAN AND ANIMAL RIGHTS}

No animals were used in this research. All human research procedures followed were in accordance with the ethical standards of the committee responsible for human experimentation (institutional and national), and with the Helsinki Declaration of 1975, as revised in 2013.

\section{CONSENT FOR PUBLICATION}

The participants participated voluntarily and provided their informed consent.

\section{AVAILABILITY OF DATA AND MATERIALS}

Not applicable.

\section{FUNDING}

None.

\section{CONFLICT OF INTEREST}

The authors declare no conflict of interest, financial or otherwise.

\section{ACKNOWLEDGEMENTS}

The authors want to express their gratitude to the supervisors for their guidance that helped to complete this research. Furthermore, the authors appreciate the assistance and cooperation of mothers who participated in this research. The authors would also like to thank the West Sumatra provincial government for providing research permits.

\section{REFERENCES}

[1] Putnick DL, Bornstein MH, Lansford JE, et al. Parental acceptancerejection and child prosocial behavior: Developmental transactions across the transition to adolescence in nine countries, mothers and fathers, and girls and boys. Dev Psychol 2018; 54(10): 1881-90. [http://dx.doi.org/10.1037/dev0000565] [PMID: 30234339]

[2] Dai J, Scherf KS. Puberty and functional brain development in humans: Convergence in findings? Dev Cogn Neurosci 2019; 39100690

[http://dx.doi.org/10.1016/j.den.2019.100690] [PMID: 31450015]

[3] Steinberg L. Risk taking in adolescence: New perspectives from brain and behavioral science. Curr Dir Psychol Sci 2007; 16(2): 55-9. [http://dx.doi.org/10.1111/j.1467-8721.2007.00475.x]

[4] Gaetz S. Safe streets for whom? Homeless youth, social exclusion, and criminal victimization. Can J Criminol Crim Justice 2004; 46(4): 
423-56.

[http://dx.doi.org/10.3138/cjccj.46.4.423]

[5] Marcum CD, Higgins GE, Ricketts ML. Potential factors of online victimization of youth: An examination of adolescent online behaviors utilizing routine activity theory. Deviant Behav 2010; 31(5): 381-410. [http://dx.doi.org/10.1080/01639620903004903]

[6] Toolis EE, Hammack PL. The lived experience of homeless youth: A narrative approach. Qual Psychol 2015; 2(1): 50.

[http://dx.doi.org/10.1037/qup0000019]

[7] Baehr J. The varieties of character and some implications for character education. J Youth Adolesc 2017; 46(6): 1153-61. [http://dx.doi.org/10.1007/s10964-017-0654-z] [PMID: 28332052]

[8] Kapetanovic S, Skoog T. The role of the family's emotional climate in the links between parent-adolescent communication and adolescent psychosocial functioning. Res Child Adolesc Psychopathol 2021; 49(2): 141-54

[http://dx.doi.org/10.1007/s10802-020-00705-9] [PMID: 32960375]

[9] Pace U, Passanisi A. "9 The role of the family in personality development," SAGE handb personal individ differ. Orig. Personal. Individ. Differ 2018; Vol. II.

[10] Gonzales NA, Wong JJ, Toomey RB, Millsap R, Dumka LE, Mauricio AM. School engagement mediates long-term prevention effects for Mexican American adolescents. Prev Sci 2014; 15(6): 929-39. [http://dx.doi.org/10.1007/s11121-013-0454-y] [PMID: 24398825]

[11] Jimenez-Iglesias A, Moreno C, Ramos P, Rivera F. What family dimensions are important for health-related quality of life in adolescence? J Youth Stud 2015; 18(1): 53-67. [http://dx.doi.org/10.1080/13676261.2014.933191]

[12] Leversen I, Danielsen AG, Birkeland MS, Samdal O. Basic psychological need satisfaction in leisure activities and adolescents' life satisfaction. J Youth Adolesc 2012; 41(12): 1588-99.

[http://dx.doi.org/10.1007/s10964-012-9776-5] [PMID: 22627625]

[13] Sarkova M, Bacikova-Sleskova M, Madarasova Geckova A, Katreniakova Z, van den Heuvel W, van Dijk JP. Adolescents' psychological well-being and self-esteem in the context of relationships at school. Educ Res 2014; 56(4): 367-78. [http://dx.doi.org/10.1080/00131881.2014.965556]

[14] Shin K, You S. Leisure type, leisure satisfaction and adolescents' psychological wellbeing. J Pacific Rim Psychol 2013; 7(2): 53-62. [http://dx.doi.org/10.1017/prp.2013.6]

[15] Tian L, Chen H, Huebner ES. The longitudinal relationships between basic psychological needs satisfaction at school and school-related subjective well-being in adolescents. Soc Indic Res 2014; 119(1): 353-72.

[http://dx.doi.org/10.1007/s11205-013-0495-4]

[16] Ayres MM, Leaper C. Adolescent girls' experiences of discrimination: An examination of coping strategies, social support, and self-esteem. J Adolesc Res 2013; 28(4): 479-508.

[http://dx.doi.org/10.1177/0743558412457817]

[17] Demaray MK, Malecki CK, Rueger SY, Brown SE, Summers KH. The role of youth's ratings of the importance of socially supportive behaviors in the relationship between social support and self-concept. J Youth Adolesc 2009; 38(1): 13-28.

[http://dx.doi.org/10.1007/s10964-007-9258-3] [PMID: 19636788]

[18] Cheah CSL, Gürsoy H, Balkaya-Ince M. Parenting and social identity contributors to character development in Muslim American adolescents. Int J Intercult Relat 2021; 81: 68-78.

[http://dx.doi.org/10.1016/j.ijintrel.2021.01.002]

[19] Hartas D. Parenting, family policy and children's well-being in an unequal society: a new culture war for parents. Springer 2014. [http://dx.doi.org/10.1057/9781137319555]

[20] Sen Chu P, Saucier DA, Hafner E. Meta-analysis of the relationships between social support and well-being in children and adolescents. J Soc Clin Psychol 2010; 29(6): 624-45.

[http://dx.doi.org/10.1521/jscp.2010.29.6.624]

[21] Danielsen AG, Samdal O, Hetland J, Wold B. School-related social support and students' perceived life satisfaction. J Educ Res 2009; 102(4): 303-20.

[http://dx.doi.org/10.3200/JOER.102.4.303-320]

[22] Piko BF, Luszczynska A, Fitzpatrick KM. Social inequalities in adolescent depression: the role of parental social support and optimism. Int J Soc Psychiatry 2013; 59(5): 474-81. [http://dx.doi.org/10.1177/0020764012440788] [PMID: 22491755]

[23] Trask-Tate A, Cunningham M, Lang-DeGrange L. The importance of family: The impact of social support on symptoms of psychological distress in African American girls. Res Hum Dev 2010; 7(3): 164-82. [http://dx.doi.org/10.1080/15427609.2010.504458]
[24] Wang MT, Eccles JS. Social support matters: longitudinal effects of social support on three dimensions of school engagement from middle to high school. Child Dev 2012; 83(3): 877-95.

[http://dx.doi.org/10.1111/j.1467-8624.2012.01745.x] [PMID: 22506836]

[25] Kirby JN. Nurturing family environments for children: Compassionfocused parenting as a form of parenting intervention. Educ Sci 2020; 10(1): 3 .

[http://dx.doi.org/10.3390/educsci10010003]

[26] Yan-Li S, Roslan S, Abdullah MC, Abdullah H. Do family environment, parental care and adolescent externalizing problem mediate the relationship between parental readiness and adolescent school performance among commuter families? Community Work Fam 2020; 23(3): 342-65.

[http://dx.doi.org/10.1080/13668803.2018.1504002]

[27] Martínez-Monteagudo MC, Delgado B, Inglés CJ, García-Fernández JM. Cyberbullying in the university setting. Relationship with family environment and emotional intelligence. Comput Human Behav 2019; 91: 220-5.

[http://dx.doi.org/10.1016/j.chb.2018.10.002]

[28] Jensen JT, Creinin MD. Family planning, population growth, and the environment. Contraception 2020; 101(3): 145-7.

[http://dx.doi.org/10.1016/j.contraception.2020.02.003] [PMID: 32059839]

[29] Bala P, Majeed A. Impact of emotional maturity and family environment on academic resilience of college students. J Crit Rev 2020; 7(18): 1574-83. [Retrieved from https://www.ejmcm.com/article_5032_13a046b54ed219b9347108d75 6188d3b.pdf].

[30] Rogers SJ, White LK, Rogers SJ, White LK. 2016. Available from: http://www.jstor.org/stable/353849

[31] Atherton OE, Schofield TJ. Personality and parenting. Guilford Publications 2021. [https://doi.org/10.1007/s10964-017-0654-z]

[32] Kuppens S, Ceulemans E. Parenting styles: A closer look at a wellknown concept. J Child Fam Stud 2019; 28(1): 168-81. [http://dx.doi.org/10.1007/s10826-018-1242-x] [PMID: 30679898]

[33] Martínez I, Murgui S, García OF, García F. Parenting in the digital era: Protective and risk parenting styles for traditional bullying and cyberbullying victimization. Comput Human Behav 2019; 90: 84-92. [http://dx.doi.org/10.1016/j.chb.2018.08.036]

[34] Smetana JG. Current research on parenting styles, dimensions, and beliefs. Curr Opin Psychol 2017; 15: 19-25.

[http://dx.doi.org/10.1016/j.copsyc.2017.02.012] [PMID: 28813261]

[35] Lerner JV, Wong CA, Weiner MB, Johnson SK. Profiles of adolescent character attributes: Associations with intentional self-regulation and character role model relationships. J Moral Educ 2020; 1-24.

[36] Wagner L. Good character is what we look for in a friend: character strengths are positively related to peer acceptance and friendship quality in early adolescents. J Early Adolesc 2019; 39(6): 864-903. [http://dx.doi.org/10.1177/0272431618791286]

[37] Sáenz VB, García-Louis C, De Las Mercédez C, Rodriguez SL. Mujeres supporting: How female family members influence the educational success of Latino males in postsecondary education. J Hisp High Educ 2020; 19(2): 169-94.

[http://dx.doi.org/10.1177/1538192718787291]

[38] Kato T. Change and continuity in the Minangkabau matrilineal system. Indonesia 1978; (25): 1-16.

[http://dx.doi.org/10.2307/3350964]

[39] Dorn LD, Susman EJ. Conceptualizing puberty as a window of opportunity for impacting health and well-being across the life span 2019; 29(1): 155-76.

[40] Gaetz S. The Invented Tradition: Hastings Kamuzu Banda and the Marginalization of Women in Malawi, 1964-1994. J Moral Educ 2020; 29(3): 1-11.

[41] Harrington NG, Giles SM, Hoyle RH, Feeney GJ, Yungbluth SC. Evaluation of the All Stars character education and problem behavior prevention program: effects on mediator and outcome variables for middle school students. Health Educ Behav 2001; 28(5): 533-46. [http://dx.doi.org/10.1177/109019810102800502] [PMID: 11575684]

[42] Natsir MHD, Suryadi A, Kamil M, Sudiapermana E. Adolescent characters in the matrilineal family in indonesia. J Nonform Educ 2020; 6(2): 115-22.

[43] Creswell J D. Research design: Qualitative, quantitative, and mixed methods approaches Sage publications. 2018; 2 .

[44] Esfandiar K, Dowling R, Pearce J, Goh E. Personal norms and the adoption of pro-environmental binning behaviour in national parks: An integrated structural model approach. J Sustain Tour 2020; 28(1): 
10-32.

[http://dx.doi.org/10.1080/09669582.2019.1663203]

[45] Ringle CM, Sarstedt M, Mitchell R, Gudergan SP. Partial least squares structural equation modeling in HRM research. Int J Hum Resour Manage 2020; 31(12): 1617-43.

[http://dx.doi.org/10.1080/09585192.2017.1416655]

[46] Sarstedt M, Ringle CM, Cheah J-H, Ting H, Moisescu OI, Radomir L. Structural model robustness checks in PLS-SEM. Tour Econ 2020; 26(4): 531-54

[http://dx.doi.org/10.1177/1354816618823921]

[47] Hair JF Jr, Hult GTM, Ringle C, Sarstedt M. A primer on partial least squares structural equation modeling (PLS-SEM). Sage publications 2016.

[48] Hair JF, Sarstedt M, Ringle CM. Rethinking some of the rethinking of partial least squares. Eur J Mark 2019.

[http://dx.doi.org/10.1108/EJM-10-2018-0665]

[49] Shmueli G. Predictive model assessment in PLS-SEM: guidelines for using PLSpredict. Eur J Mark 2019.

[http://dx.doi.org/10.1108/EJM-02-2019-0189]

[50] Doi S, Isumi A, Fujiwara T. The Association between Parental Involvement Behavior and Self-Esteem among Adolescents Living in Poverty: Results from the K-CHILD Study. Int J Environ Res Public Health 2020; 17(17): 6277.

[http://dx.doi.org/10.3390/ijerph17176277] [PMID: 32872279]

[51] Schofield TJ, Atherton OE. Personality and parenting. Handb. Personal. Theory Res 2018.

[52] Krauss S, Orth U, Robins RW. Family environment and self-esteem development: A longitudinal study from age 10 to 16 . J Pers Soc Psychol 2020; 119(2): 457-78.

[http://dx.doi.org/10.1037/pspp0000263] [PMID: 31535888]

[53] Self-esteem, bullying perpetration/victimization and perceived parental support in a nationally representative sample of australian students. Rev Cercet Interv Soc 2020; 69: 49-68.

[http://dx.doi.org/10.33788/rcis.69.3]

[54] Hsieh Y-P, Shen AC-T, Hwa H-L, Wei H-S, Feng J-Y, Huang SC-Y. Associations between child maltreatment, dysfunctional family environment, post-traumatic stress disorder and children's bullying perpetration in a national representative sample in taiwan. J Fam Violence 2020; 1-10

[http://dx.doi.org/10.1007/s10896-020-00144-6]

[55] Hong JS, Fisher BW, Espelage DL. An introduction to the special issue: Family violence and youth violence-examining the connections from interdisciplinary perspectives (an extension of anna costanza baldry's legacy). J Fam Violence 2020; 1-4.

[http://dx.doi.org/10.1007/s10896-020-00197-7]

[56] Bègue A, Richard A-L, Jousselme C. The child's conflictual family environment https://europepmc.org/article/med/328771052020. Wang B, Luo X, Yue A, Tang L, Shi Y. Family environment in rural China and the link with early childhood development. Early Child Dev Care 2020; $1-14$

[57] Ferrar SJ, Stack DM, Dickson DJ, Serbin LA, Ledingham J, Schwartzman AE. Maternal socialization responses to preschoolers' success and struggle: Links to contextual factors and academic and cognitive outcomes. J Res Child Educ 2019; 33(3): 363-81. [http://dx.doi.org/10.1080/02568543.2019.1607787]

[58] Neppl TK, Senia JM, Donnellan MB. Effects of economic hardship: Testing the family stress model over time. J Fam Psychol 2016; 30(1): 12-21. [https://doi.org/https://doi.org/10.1037/fam0000168]. [http://dx.doi.org/10.1037/fam0000168] [PMID: 26551658]

[59] Liu Y, Lachman ME. Socioeconomic status and parenting style from childhood: Long-term effects on cognitive function in middle and later adulthood. J Gerontol Ser B 2019; 74(6): e13-24.

[http://dx.doi.org/10.1093/geronb/gbz034] [PMID: 30888020]
[60] Luo S, Liu Y, Zhang D. Socioeconomic status and young children's problem behaviours-mediating effects of parenting style and psychological suzhi. Early Child Dev Care 2019; 1-11. [http://dx.doi.org/10.1080/03004430.2019.1608196]

[61] Hosokawa R, Katsura T. Marital relationship, parenting practices, and social skills development in preschool children. Child Adolesc Psychiatry Ment Health 2017; 11(1): 2.

[http://dx.doi.org/10.1186/s13034-016-0139-y] [PMID: 28077966]

[62] Awit Y. The relationship between commitment to the marital relation and the parenting style parents of Lebanese school aged children. Notre Dame University-Louaize. Retrieved from 2019.

[63] Le A-V, et al. Exploration of youth's digital competencies: a dataset in the educational context of Vietnam. Data (Basel) 2019; 4(2): 69. [http://dx.doi.org/10.3390/data4020069]

[64] Matama R, Mkwizu KH. Antecedents of family conflict in uganda 2020 .

https://doi.org/https://journals.library.ualberta.ca/cjfy/index.php/c jfy/article/view/29596

[65] Hombrados-Mendieta MI, Gomez-Jacinto L, Dominguez-Fuentes JM, Garcia-Leiva P, Castro-Travé M. Types of social support provided by parents, teachers, and classmates during adolescence. J Community Psychol 2012; 40(6): 645-64.

[http://dx.doi.org/10.1002/jcop.20523]

[66] Gunuc S, Dogan A. The relationships between Turkish adolescents' Internet addiction, their perceived social support and family activities. Comput Human Behav 2013; 29(6): 2197-207. [http://dx.doi.org/10.1016/j.chb.2013.04.011]

[67] Zhu X, Huebner ES, Tian L. A person-centered longitudinal analysis of adolescents' loneliness and social anxiety: Clusters, predictors, and outcomes. Sch Psychol 2019; 34(5): 576-89. [http://dx.doi.org/10.1037/spq0000328] [PMID: 31246063]

[68] Liu C, Liu Z, Yuan G. Cyberbullying victimization and problematic Internet use among Chinese adolescents: Longitudinal mediation through mindfulness and depression. J Health Psychol 2020.1359105320934158 [PMID: 32567374]

[69] Santrock J. Essentials of life-span development. McGraw-Hill Higher Education 2015.

[70] Blanchy S. A matrilineal and matrilocal Muslim society in flux negotiating gender and family relations in the Comoros. Africa J Int African Inst 2019; 89(1): 21-39.

[http://dx.doi.org/10.1017/S0001972018000682]

[71] Walker LJ. The family context for moral development. J Moral Educ 1999; 28(3): 261-4.

[http://dx.doi.org/10.1080/030572499103061]

[72] Sung M. A study of adults ' perception and needs for smart learning. Procedia Soc Behav Sci 2015; 191: 115-20

[http://dx.doi.org/10.1016/j.sbspro.2015.04.480]

[73] Waylen A, Stewart-Brown S. Factors influencing parenting in early childhood: A prospective longitudinal study focusing on change. Child Care Health Dev 2010; 36(2): 198-207.

[http://dx.doi.org/10.1111/j.1365-2214.2009.01037.x] [PMID: 20015278]

[74] Alonso-Stuyck P. Parenting and healthy teenage lifestyles. Int J Environ Res Public Health 2020; 17(15): 5428. [http://dx.doi.org/10.3390/ijerph17155428] [PMID: 32731468]

[75] Barni D, Ranieri S, Scabini E, Rosnati R. Value transmission in the family: Do adolescents accept the values their parents want to transmit? J Moral Educ 2011; 40(1): 105-21. [http://dx.doi.org/10.1080/03057240.2011.553797]

[76] Macfarlan SJ, Quinlan RJ, Post E. Emergent matriliny in a matrifocal, patrilineal population: A male coalitionary perspective. 2019. [http://dx.doi.org/10.1098/rstb.2018.0073]

\section{(C) 2021 Natsir et al.}

This is an open access article distributed under the terms of the Creative Commons Attribution 4.0 International Public License (CC-BY 4.0), a copy of which is available at: https://creativecommons.org/licenses/by/4.0/legalcode. This license permits unrestricted use, distribution, and reproduction in any medium, provided the original author and source are credited. 